\title{
Acute Cocaine Induces Fast Activation of D1 Receptor and Progressive Deactivation of D2 Receptor Striatal Neurons: In Vivo Optical Microprobe $\left[\mathrm{Ca}^{2+}\right]_{\mathrm{i}}$ Imaging
}

\author{
Zhongchi Luo, ${ }^{1}$ Nora D. Volkow, ${ }^{3}$ Nathaniel Heintz, ${ }^{4}$ Yingtian Pan, ${ }^{1}$ and Congwu Du ${ }^{2,5}$ \\ Departments of ${ }^{1}$ Biomedical Engineering and ${ }^{2}$ Anesthesiology, Stony Brook University, Stony Brook, New York 11794, ${ }^{3}$ National Institute of Alcohol Abuse \\ and Alcoholism and National Institute on Drug Abuse, National Institutes of Health, Bethesda, Maryland 20892, ${ }^{4}$ Laboratory of Molecular Biology, Howard \\ Hughes Medical Institute, The Rockefeller University, 1230 York Avenue, New York, New York 10065, and ${ }^{5}$ Medical Department, Brookhaven National \\ Laboratory, Upton, New York 11973
}

Cocaine induces fast dopamine increases in brain striatal regions, which are recognized to underlie its rewarding effects. Both dopamine D1 and D2 receptors are involved in cocaine's reward but the dynamic downstream consequences of cocaine effects in striatum are not fully understood. Here we used transgenic mice expressing EGFP under the control of either the D1 receptor (D1R) or the D2 receptor (D2R) gene and microprobe optical imaging to assess the dynamic changes in intracellular calcium ([Ca $\left.\left.{ }^{2+}\right]_{\mathrm{i}}\right)$ responses (used as marker of neuronal activation) to acute cocaine in vivo separately for D1R-versus D2R-expressing neurons in striatum. Acute cocaine (8 mg/kg, i.p.) rapidly increased $\left[\mathrm{Ca}^{2+}\right]_{\mathrm{i}}$ in D1R-expressing neurons $(10.6 \pm 3.2 \%)$ in striatum within $8.3 \pm 2.3$ min after cocaine administration after which the increases plateaued; these fast $\left[\mathrm{Ca}^{2+}\right]_{\mathrm{i}}$ increases were blocked by pretreatment with a D1R antagonist (SCH23390). In contrast, cocaine induced progressive decreases in $\left[\mathrm{Ca}^{2+}\right]_{\mathrm{i}}$ in $\mathrm{D} 2 \mathrm{R}$-expressing neurons $(10.4 \pm 5.8 \%)$ continuously throughout the 30 min that followed cocaine administration; these slower $\left[\mathrm{Ca}^{2+}\right]_{\mathrm{i}}$ decreases were blocked by pretreatment with a D2R antagonist (raclopride). Since activation of striatal D1R-expressing neurons (direct-pathway) enhances cocaine reward, whereas activation of D2Rexpressing neurons suppresses it (indirect-pathway) (Lobo et al., 2010), this suggests that cocaine's rewarding effects entail both its fast stimulation of D1R (resulting in abrupt activation of direct-pathway neurons) and a slower stimulation of D2R (resulting in longer-lasting deactivation of indirect-pathway neurons). We also provide direct in vivo evidence of $\mathrm{D} 2 \mathrm{R}$ and $\mathrm{D} 1 \mathrm{R}$ interactions in the striatal responses to acute cocaine administration.

\section{Introduction}

Cocaine induces fast DA increases in the nucleus accumbens that are associated with its rewarding effects (Di Chiara and Imperato, 1988; Koob and Bloom, 1988). Indeed, the rate at which cocaine enters the brain and increases DA modulates its rewarding effects; the faster the increases, the stronger the reward (Balster and Schuster, 1973). Both D1 and D2 DA receptors (D1Rs, D2Rs) are involved in cocaine's reward (Caine and Koob, 1994) but the specific effects of cocaine on D1R versus $\mathrm{D} 2 \mathrm{R}$ in vivo and in particular their dynamics are not completely understood. Here

\footnotetext{
Received May 6, 2011; revised July 18, 2011; accepted July 21, 2011.

Author contributions: N.D.V., Y.P., and C.D. designed research; Z.L. performed research; Z.L. analyzed data; Z.L., N.D.V., N.H., Y.P., and C.D. wrote the paper.

This work was supported in part by NIH Grants K25-DA021200 (C.D.), 2R01-DK059265 (Y.P.), and 1RC1DA028534 (C.D., Y.P.), and by the Brookhaven National Laboratory (LDRD 10-023, C.D.), the Department of Energy, and the NIAAA Intramural Research Program (N.D.V.). We thank Dr. Paul Greengard of the Rockefeller University for kindly providing DrD2-EGFP mouse breeders and Dr. Myriam Heiman for suggestions on managing the colony.

The authors declare no conflicting financial interests.

Correspondence should be addressed to Congwu Du, Medical Department, Building 490, Bell Avenue, Brookhaven National Laboratory, Upton, NY 11973, E-mail: congwu@bnl.gov; or Yingtian Pan, Room G11, BioEngineering Building, Biomedical Engineering Department, Stony Brook University, Stony Brook, NY 11794-5281, E-mail: yinpan@notes.cc.sunysb.edu.

DOI:10.1523/JNEUROSCI.2369-11.2011

Copyright $\odot 2011$ the authors $\quad 0270-6474 / 11 / 3113180-11 \$ 15.00 / 0$
}

we test the hypothesis that the effects of cocaine and their temporal dynamics on neuronal activity would differ for D1Rexpressing versus D2R-expressing neurons.

Coupling of electrical activity to intracellular calcium levels $\left(\left[\mathrm{Ca}^{2+}\right]_{\mathrm{i}}\right)$ is crucial for neurotransmission (Sudhof, 2004) and measurements of $\left[\mathrm{Ca}^{2+}\right]_{\mathrm{i}}$ in neurons are used as markers of neuronal activity (Helmchen and Waters, 2002). In striatum, DA stimulation of D2R decreases $\mathrm{Ca}^{2+}$ entry into the cell, inhibiting medium spiny neurons (MSNs) of the indirect pathway (Albin et al., 1989; Gerfen, 1992), whereas DA activation of D1R increases $\left[\mathrm{Ca}^{2+}\right]_{\mathrm{i}}$, increasing excitability of MSNs from the direct pathway (Surmeier et al., 1995). Thus, we hypothesized that acute cocaine would decrease $\left[\mathrm{Ca}^{2+}\right]_{\mathrm{i}}$ in D2R-expressing neurons and increase it in D1R-expressing neurons. We also hypothesized that since cocaine abruptly increases DA (peaking at 1-2 min when administered intravenously) after which its concentration rapidly decreases (half-peak clearance 20-25 min) (España et al., 2008), it would result in fast and transitory stimulation of low-affinity D1R (stimulated by high DA concentrations), and result in longer-lasting stimulation of high-affinity D2R (stimulated by much lower DA concentrations) (Goto and Grace, 2005).

Studies of cocaine's effects on neuronal $\mathrm{Ca}^{2+}$ level were done in vitro (isolated cells or tissue slices) and thus limited by the 
Table 1. Experimental design and animal allocation

\begin{tabular}{|c|c|c|c|c|c|c|c|c|}
\hline \multirow[b]{2}{*}{$m$} & \multicolumn{2}{|l|}{$\begin{array}{l}\text { Experiment 1: Saline } \\
\mu \mathrm{N} \text { Probe }\end{array}$} & \multicolumn{2}{|c|}{$\begin{array}{l}\text { Experiment 2: Cocaine only } \\
\mu \mathrm{N} \text { Probe }\end{array}$} & \multirow[t]{2}{*}{$\mu \mathrm{P}$} & \multicolumn{2}{|c|}{$\begin{array}{l}\text { Experiment 3: Cocaine }+ \text { antagonism } \\
\mu \mathrm{N} \text { Probe }\end{array}$} & \multirow{2}{*}{$\begin{array}{l}\text { Experiment 4: Cocaine }+ \text { cross-antagonism } \\
\mu N \text { Probe } \\
\text { Striatum }\end{array}$} \\
\hline & Cortex (layer 5-6) & Striatum & Cortex (layer 5-6) & Striatum & & Cortex (layer 5-6) & Striatum & \\
\hline Drd1-EGFP & 4 & 3 & 4 & 4 & 3 & 3 & 3 & 3 \\
\hline Drd2-EGFP & - & 3 & - & 7 & 3 & - & 4 & 3 \\
\hline
\end{tabular}

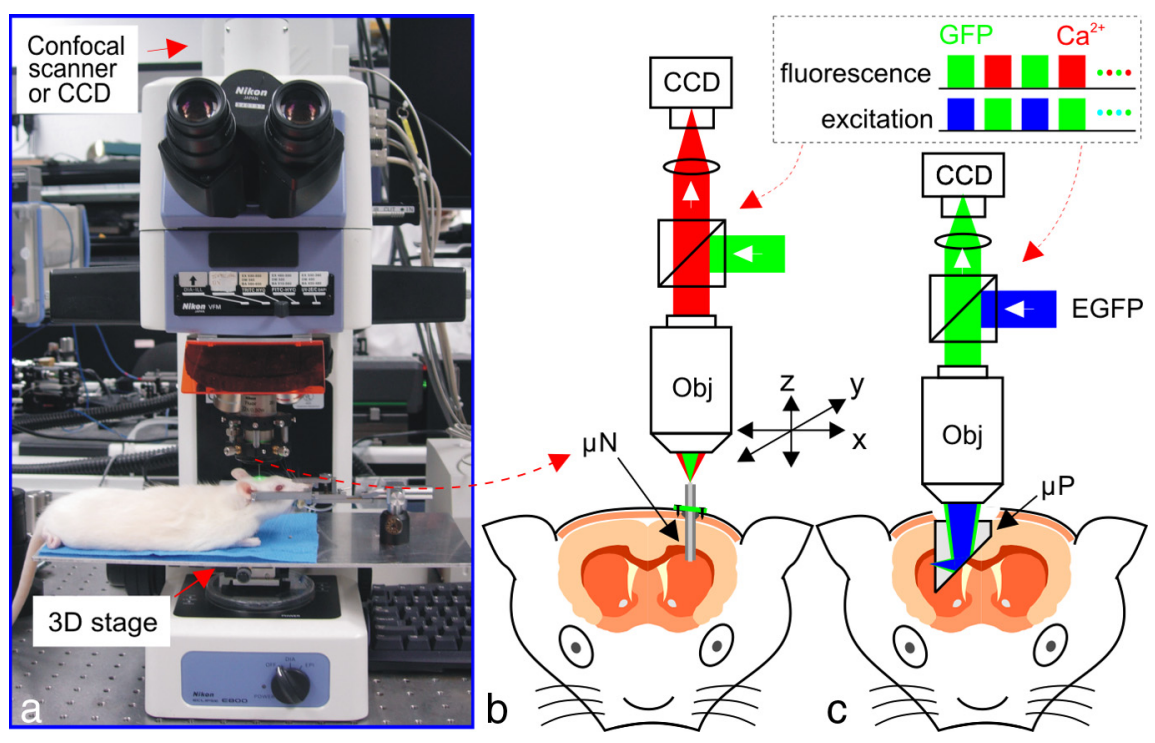

Figure 1. Microprobe-based fluorescence microscope for in vivo deep brain imaging. $\boldsymbol{a}$, A modified fluorescence microscope for simultaneous EGFP and $\operatorname{Rhod}_{2}-\left[\mathrm{Ca}^{2+}\right]_{\mathrm{i}}$ imaging. $\boldsymbol{b}, \mu \mathrm{N}$ catheter and the 3D motorized micro-stage assembly for deep brain imaging. $c, \mu \mathrm{P}$ for in vivo imaging across different brain regions. Obj, Objective; Ex, excitation beams; Em, emission beams. The dashed box illustrates the time sequence for dual-channel fluorescence illumination and imaging.

removal of the projections that in vivo modulate DA cell activity and release and by single time point measurements. Quantitative methods for imaging $\left[\mathrm{Ca}^{2+}\right]_{\mathrm{i}}$ in vivo in the striatum have been technically challenging. Thus while confocal and multiphoton microscopy provide superior cellular resolution for $\left[\mathrm{Ca}^{2+}\right]_{\mathrm{i}} \mathrm{flu}-$ orescence imaging, they have limited imaging depth (Helmchen and Denk, 2002; Zipfel et al., 2003). Recent advances in microprobe techniques [e.g., the gradual refractive index lens (Jung et al., 2004; Levene et al., 2004) and micro-prisms (Chia and Levene, 2009, 2010)] now allow for dynamic $\left[\mathrm{Ca}^{2+}\right]_{\mathrm{i}}$ measurements in subcortical brain regions in vivo.

Here, we apply for the first time these imaging approaches to assess the dynamic effects of cocaine on D1R- versus D2Rexpressing neurons in striatum in the intact brain. For this purpose we measured cocaine-induced $\left[\mathrm{Ca}^{2+}\right]_{i}$ changes (using the fluorescent $\left[\mathrm{Ca}^{2+}\right]_{\mathrm{i}}$ indicator $\mathrm{Rhod}_{2}$ ) in transgenic mice that expressed EGFP under the control of either the D1R or the D2R gene (Gong et al., 2003). An epifluorescence microscope was integrated with optical microprobes [either a micro-needle lens $(\mu \mathrm{N})$ or a micro-prism $(\mu \mathrm{P})]$ to image EGFP-expressing individual D1R or D2R neurons while simultaneously imaging $\left[\mathrm{Ca}^{2+}\right]_{\mathrm{i}}$ in vivo, in real time in both cortex and striatum.

\section{Materials and Methods}

Animals. Drd1-EGFP and Drd2-EGFP bacterial artificial chromosome (BAC) transgenic mice generated by the Gensat BAC transgenic project were used (Gong et al., 2003). These animals were divided into different groups for experiments summarized in Table 1. All animal protocols were in accordance with National Institute of Health Guide for the Care and Use of Laboratory Animals and were approved by the Institutional
Animal Care and Use Committees of State University of New York at Stony Brook and Brookhaven National Laboratory.

Surgical preparation. The mice were anesthetized with $2 \%$ isoflurane mixed in pure $\mathrm{O}_{2}$ and their heads were then immobilized using a customized stereotaxic frame. A cranial window $(\phi 1 \sim 1.5 \mathrm{~mm})$ was created $\sim 2 \mathrm{~mm}$ lateral and $0.4 \mathrm{~mm}$ anterior to bregma and above the striatum (i.e., caudate-putamen nucleus region; Hof and Young, 2000; Paxinos and Franklin, 2004). The $\left[\mathrm{Ca}^{2+}\right]_{\mathrm{i}}$ fluorescence indicator, $\operatorname{Rhod}_{2} / \mathrm{AM}(12.5 \mu \mathrm{g} / 100 \mu \mathrm{l}$, Invitrogen), was slowly infused into the brain using a microinfusion pump (3 $\mu \mathrm{l} / \mathrm{min})$. Imaging was started at $1 \mathrm{~h}$ after Rhod $_{2}$ infusion to ensure maximal intracellular uptake of $\operatorname{Rhod}_{2}$. The labeling distribution profile of $\operatorname{Rhod}_{2}$ was $\sim \phi 1$ $\mathrm{mm}$ around the loading site.

Drug treatment during the experiments. In each mouse, a bolus of $8 \mathrm{mg} / \mathrm{kg}$ cocaine $\cdot \mathrm{HCl}$ (Sigma-Aldrich) was injected intraperitoneally. For the groups in Experiment 3 (Table 1), the mice were injected with either D1R antagonist (a bolus dose of $0.075 \mathrm{mg} / \mathrm{kg} \mathrm{SCH} 23390$, Sigma-Aldrich) or D2R antagonist (a bolus dose of $3 \mathrm{mg} / \mathrm{kg}$ raclopride, Sigma-Aldrich), which were administered intraperitoneally at 30 min before cocaine injection in the Drd1EGFP transgenic mice and Drd2-EGFP transgenic mice, respectively. We chose SCH23390 and raclopride since these are validated antagonists for D1R and D2R, respectively, and we selected doses that have been commonly used in preclinical studies (Doherty et al., 2008; Williams and Undieh, 2010; Choleris et al., 2011; Lange et al., 2011).

In vivo microprobe imaging. The $\mu \mathrm{N}$ approach enabled us to measure dynamic changes of $\left[\mathrm{Ca}^{2+}\right]_{\mathrm{i}}$ in D1R and D2R neurons in cortex and striatum; whereas the $\mu \mathrm{P}$ approach provided a large field of view that allowed assessment of the distribution of these neurons within the cortical layers and the striatum together with their $\left[\mathrm{Ca}^{2+}\right]_{\mathrm{i}}$ differences before and after acute cocaine challenge. Figure 1 illustrates the endomicroscopic approach, which employs interchangeable $\mu \mathrm{N}$ and $\mu \mathrm{P}$ probes to image cortical and subcortical brain regions in vivo. After anesthesia and surgical preparation, the animal together with the stereotaxic frame was mounted on a motorized 3D stage adapted to a modified upright fluorescence microscope (E800, Nikon) as shown in Figure $1 a$. Figure $1 b$ illustrates a $\mu$ N probe which was a custom GRIN lens $(\phi 1 \mathrm{~mm} \times 20 \mathrm{~mm})$ that relayed the image from the mouse brain at the distal end of the needle probe back to the focal plane of the microscope objective [e.g., PlanFluo $20 \times / 0.5$ numerical aperture (NA), Nikon]. A custom motorized 3D micro-stage (Fig. 1a) facilitated accurate light coupling and focal tracking between the $\mu \mathrm{N}$ probe and the microscope objective as shown in Fig. $1 b$, which allowed the focus to be finely placed on the depth dominated by GFP-expressing neurons. The $\mu \mathrm{N}$ probe was first inserted into the cortical brain at a precise depth for cortical ( $1 \mathrm{~mm}$ below the surface) and for striatal imaging ( $3 \mathrm{~mm}$ below the surface). During this procedure, special attention was paid to avoid disruption of large vascular vessels, and minor bleeding was occluded by flushing saline solution. For dual-channel EGFP and $\mathrm{Rhod}_{2}-\mathrm{Ca}^{2+}$ fluorescence imaging, gated sequential illumination for excitation of EGFP $\left(\lambda_{\mathrm{ex}}=460-500 \mathrm{~nm}\right)$ and $\mathrm{Rhod}_{2}-\mathrm{Ca}^{2+}\left(\lambda_{\mathrm{ex}}=530-550 \mathrm{~nm}\right)$ was used to minimize photon bleach- 
ing. $\mathrm{Rhod}_{2}-\left[\mathrm{Ca}^{2+}\right]_{\mathrm{i}}$ and EGFP fluorescence emissions of D1R or D2R neurons were collected by TRITC-HYQ [excitation filter (EX): $530-550 \mathrm{~nm}$, dichroic mirror (DM): $565 \mathrm{~nm}$, barrier or emission filter (BA): 590 $650 \mathrm{~nm}$, Chroma] and FITC-HYQ (EX: $460-$ $500 \mathrm{~nm}$, DM: $505 \mathrm{~nm}$, BA: $510-560 \mathrm{~nm}$, Chroma) epifluorescence cubes, respectively. The images in cortical and striatal brain regions were acquired using a CCD camera (iXon ${ }^{+}$, $1 \mathrm{M}$ pixels, $8 \mu \mathrm{m} /$ pixel, Andor) synchronized with the fluorescence excitation. During the experiment, full-field $\mu \mathrm{N}$ images (FOV: $\phi 250$ $\mu \mathrm{m}$ ) were recorded continuously at $28 \mathrm{fps}$ from baseline $t \approx-5 \mathrm{~min}$ to $t \approx 30 \mathrm{~min}$ after administration of cocaine or saline.

In parallel to $\mu \mathrm{N}$ probe, Figure $1 c$ illustrates a $\mu \mathrm{P}$ probe that permitted in vivo imaging of cortical and striatal brain regions. A custom $1 \times 2 \mathrm{~mm}^{2}$ right-angled micro-prism which was coated with anti-reflection coatings to minimize surface reflections and ensure high light throughput was fully inserted into the mouse brain. After the prism surface was cleaned by flushing saline solution, a microscope objective with adjustable aberration (PlanFluo $40 \times / 0.6 \mathrm{NA}$, Nikon) was used to search and dynamically focus at the plane dominated by GFP-expressing neurons adjacent to the vertical surface of the prism. The FOV per frame is limited to $0.2 \times 0.2 \mathrm{~mm}^{2}$; however, scanning the micro-stage transversely along the ridge of the prism projected the images across different depths of brain regions from the cortex to the striatum. To minimize photobleaching, the panoramic scan was only performed at two time points, i.e., at baseline $(t=-5 \mathrm{~min})$ and at $25 \mathrm{~min}$ after cocaine or saline injection.

Imaging processing and statistical analysis. The $\mu \mathrm{N}$ images of $\mathrm{Rhod}_{2}-$ $\left[\mathrm{Ca}^{2+}\right]_{\mathrm{i}}$ fluorescence were stacked sequentially and registered so that individual cells were delineated as regions of interest (ROIs). They were then coregistered with the EGFP images to identify $\left[\mathrm{Ca}^{2+}\right]_{\mathrm{i}}$ from EGFP neurons (D1R or D2R) and non-EGFP cells. The time course of the $\left[\mathrm{Ca}^{2+}\right]_{\mathrm{i}}$ changes $\left.\left(\Delta \mathrm{Ca}^{2+}\right]_{\mathrm{i}}\right)$ in each cell was detected by tracing the mean intensity within the ROI through the $\mathrm{Rhod}_{2}$ fluorescence image stack and normalized to the mean basal level (i.e., $t<0$ ). To identify how fast the $\left[\mathrm{Ca}^{2+}\right]_{\mathrm{i}}$ changes occurred in D1R-expressing or D2R-expressing neurons and to assess whether the dynamics of these changes differed [i.e., Fig. $2 a$ illustrates two distinct dynamic phases in D1R neurons: a "fast" (phase I) and a "slow" (phase II)], we applied a linear curve fitting method to the time course of $\Delta\left[\mathrm{Ca}^{2+}\right]_{\mathrm{i}}$ in each GFP neurons to determine their slopes ( $k_{1}$ for phase I, $k_{2}$ for phase II). The same method to analyze the two phases observed for D1R was applied to the D2Rexpressing neurons (Fig. $2 b$ ). Then, the ratio of the slopes between the two phases (i.e., $r=k_{2} / k_{1}$ ) was calculated and statistically analyzed for D1R- and D2R-expressing neurons. If $r \rightarrow 0$, the dynamics between these two phases differed significantly, thus theoretically confirming two distinct phases (Fig. 2a); whereas if $r \rightarrow 1$, the dynamics between these two phases did not differ significantly, thus confirming only one phase (Fig. $2 b$ ). For D1R-expressing neurons, we accordingly estimated the intersection time point of the fitting lines between these phases and defined this as "turning point" $\left(t_{\mathrm{p}}\right)$. The $\Delta\left[\mathrm{Ca}^{2+}\right]_{\mathrm{i}}$ at $t=25 \mathrm{~min}$ was used to represent a plateau level (i.e., phase II) after cocaine or saline challenge, for which its relative change against the baseline was averaged over different cells of the same type within an individual mouse ( $n$ : number of cells) as mean \pm SD for each mouse and then averaged across different mice ( $m$ : number of mice) in each experimental group. Comparisons were analyzed using two-tail Student's $t$ tests.

For $\mu \mathrm{P}$ images, the panoramic EGFP and $\mathrm{Rhod}_{2}$ fluorescence images were assembled by aligning and registering individual images using the position $(x, y$; here $x$ refers to the lateral position and $y$ the depth within the brain) encoded on the motorized micro-stage. Specifically in performing the $\mu \mathrm{P}$ imaging, we searched for the ROIs in the striatum that had the densest concentration of GFP-expressing neurons (by $x, y$ adjustments) to obtain the strongest GFP signals (by focusing $z$ adjustment, $z$ refers to the distance between $\mu \mathrm{P}$ surface and the objective). This was done to avoid the bleaching of $\left[\mathrm{Ca}^{2+}\right]_{\mathrm{i}}$-Rhod2 fluorescence that would occur if we adjusted the focus for each frame but that does not occur for GFP. For this purpose we prescanned a long line (along $y+a x$ for highest GFP turnouts; $a$ is a coefficient for lateral shift along $x$-axis) with focus $z_{\mathrm{k}}$ optimized for each frame $\left(y_{\mathrm{k}}\right)$ based on the strongest GPF signals, which was stored in the PC, programmed to later automatically image the $\left[\mathrm{Ca}^{2+}\right]_{\mathrm{i}}$-Rhod2 fluorescence. Thus the panoramic regions selected for EGFP and $\left[\mathrm{Ca}^{2+}\right]_{\mathrm{i}}$ images during basal and after cocaine periods were in the same exact location, but the striatal regions might be slightly different though overall in the close vicinity for the various mice imaged. The $\left[\mathrm{Ca}^{2+}\right]_{\mathrm{i}}$ fluorescence intensities at $t=25 \mathrm{~min}$ after cocaine or saline were measured in individual EGFP-expressing neurons and normalized against their mean basal levels (i.e., $t<0$ ). Their relative $\mathrm{Ca}^{2+}$ changes were averaged over different cells ( $n$ : number of cells) as mean \pm SD for each brain region. Student's $t$ test analysis were used to evaluate the significance of the changes.

It should be noted that the statistical analyses in Figures 3-7 (see below) were conducted based on the cells of the same type within an individual mouse and compared with their baseline (i.e., $\Delta\left[\mathrm{Ca}^{2+}\right]_{\mathrm{i}}=0$ ), whereas the statistical analyses in Figure 8 (see below) were conducted across the mice of the same experimental group.

\section{Results}

In vivo EGFP images of D1R- and D2R-expressing neurons Figure $3 a 1$ shows a $\mu \mathrm{P}$ image of a D1R-EGFP mouse brain in vivo $\left(\lambda_{\mathrm{em}} \approx 520 \mathrm{~nm}\right)$. This panoramic image was obtained by sequentially scanning cortical and subcortical brain regions, i.e., from $z=0.74 \mathrm{~mm}$ to $z=2.47 \mathrm{~mm}$ of depths below the cortical surface, covering the cortex (layers 5-6: $z=0.74-1.62$ $\mathrm{mm})$, the corpus callosum $(z=1.62-1.76 \mathrm{~mm})$, and the striatum $(z=1.76-2.47 \mathrm{~mm})$ and identifies D1R-expressing neurons in cortex and striatum. Similarly, Figure $3 b 1$ shows an in vivo $\mu \mathrm{P}$ image of a D2R-EGFP mouse brain from cortex to striatum and identifies $\mathrm{D} 2 \mathrm{R}$-expressing neurons primarily in the striatum. 


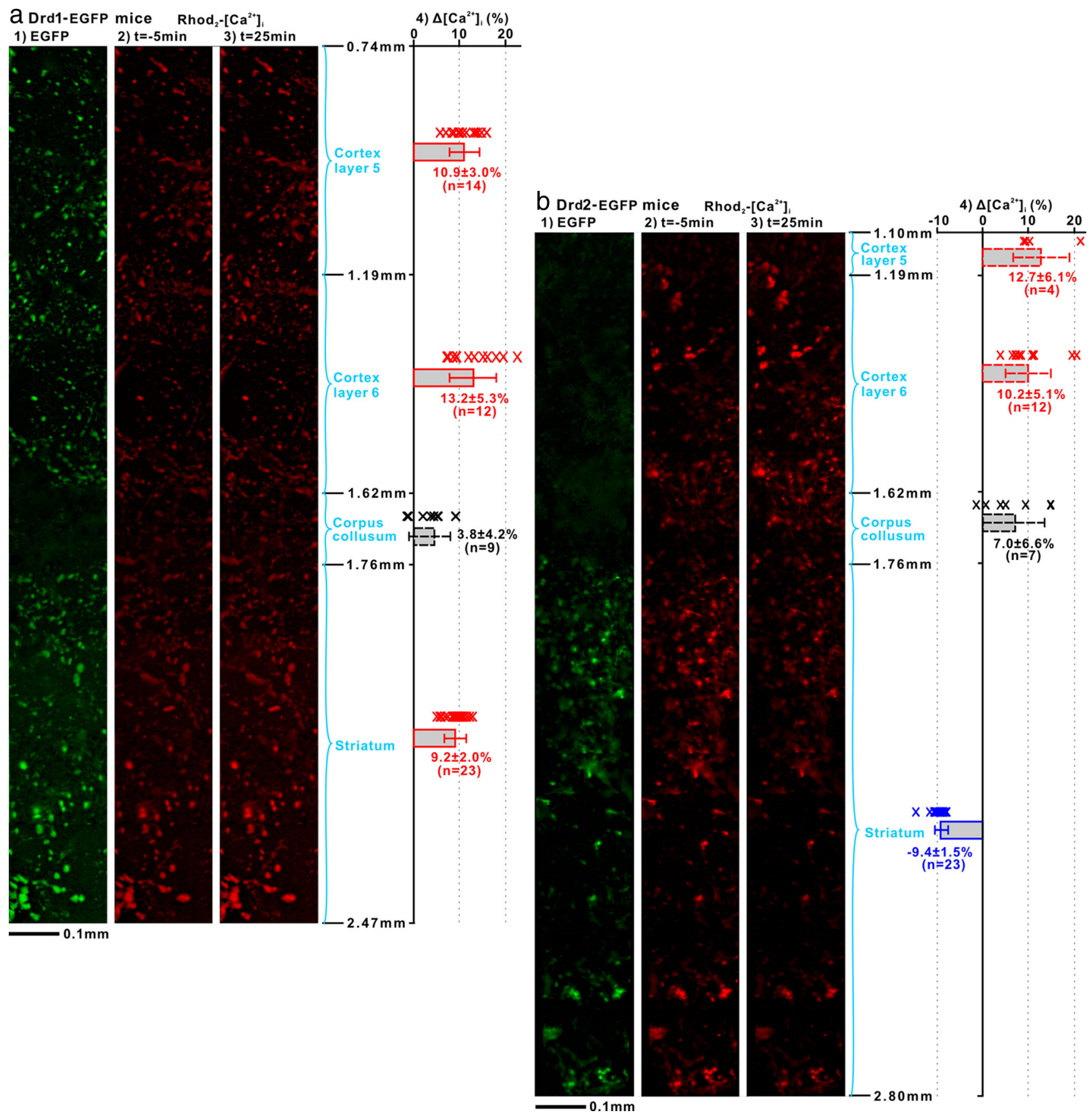

Figure 3. $\mu \mathrm{P}$ images of cocaine-evoked $\left[\mathrm{Ca}^{2+}\right]_{i}$ changes in Drd1- and Drd2-EGFP transgenic mouse brains in vivo. 1, Panoramic fluorescence images of D1R-EGFP-expressing neurons (a) or D2R-EGFP-expressing neurons $(\boldsymbol{b})$ across 4 anatomic brain regions based on their depths with respect to the cortical surface, i.e., cortical layers 5-6, corpus collosum, and striatum. 2, 3, $\operatorname{Rhod}_{2}-\left[\mathrm{Ca}^{2+}\right]_{\mathrm{i}}$ images at baseline $(t=-5 \mathrm{~min})$ and at $t=25$ min after cocaine injection. $4,\left[\mathrm{Ca}^{2+}\right]_{\mathrm{i}}$ changes $\left(\Delta\left[\mathrm{Ca}^{2+}\right]_{\mathrm{i}}\right.$ ) expressed as mean \pm SD for D1R neurons (solid red), D2R neurons (solid blue), non-D1 or -D2 cells (dashed black), and likely D1R neurons (dashed red). Cocaine evoked significant $\left[\mathrm{Ca}^{2+}\right]_{\mathrm{i}}$ increases in both cortical and striatal D1R neurons $(p<0.0001)$ and significant $\left[\mathrm{Ca}^{2+}\right]_{\mathrm{i}}$ decreases in striatal D2R neurons $(p<0.0001)$. Note that the depth of imaging though similar for both mice, it is deeper for the Drd2-EGFP transgenic mouse than for the Drd1-EGFP mouse.

Effects of cocaine on $\left[\mathrm{Ca}^{2+}\right]_{\mathrm{i}}$ in D1R- and D2R-expressing neurons

Simultaneous $\mu \mathrm{P}$ imaging of D1R-EGFP and $\mathrm{Rhod}_{2}-\mathrm{Ca}^{2+}$ fluorescence $\left(\lambda_{\mathrm{em}} \approx 590 \mathrm{~nm}\right.$ ) allowed us to monitor $\left[\mathrm{Ca}^{2+}\right]_{\mathrm{i}}$ changes in D1R-expressing neurons in cortex and striatum in response to cocaine $\left(8 \mathrm{mg} / \mathrm{kg}\right.$, i.p.). Figure $3 a, 2$ and 3 , shows the $\mathrm{Ca}^{2+}$ fluorescence images at baseline $(t=-5 \mathrm{~min})$ and at $25 \mathrm{~min}$ after cocaine administration $(t=25 \mathrm{~min})$, respectively. Quantification of cocaine-induced $\mathrm{Ca}^{2+}$ increases corresponded to $10.9 \pm 3.0 \%$ $(n=14, p<0.0001)$ for layer 5 and $13.2 \pm 5.3 \%(n=12$, $p<0.0001)$ for layer 6 in cortex, and to $9.2 \pm 2.0 \%(n=23, p<$ 0.0001 ) in striatum (Fig. 3a4).

Figure $3 b, 2$ and 3 , shows the $\mu \mathrm{P}$ images of $\left[\mathrm{Ca}^{2+}\right]_{\mathrm{i}}$ fluorescence across cortical layers 5-6 and in striatum in a Drd2-EGFP mouse at baseline $(t=-5 \mathrm{~min})$ and at $t=25 \mathrm{~min}$ after cocaine administration. Interestingly, Figure $3 b 4$ shows that in this mouse, cocaine decreased $\left[\mathrm{Ca}^{2+}\right]_{\mathrm{i}}$ to $-9.4 \pm 1.5 \%(n=23, p<$ $0.0001)$ in striatal D2R neurons while it increased $\left[\mathrm{Ca}^{2+}\right]_{\mathrm{i}}$ in striatal non-GFP cells to $12.7 \pm 6.1 \%$ and to $10.2 \pm 5.1 \%$ in cortical layers $5(n=4, p=0.026)$ and $6(n=12, p<0.0001)$, 

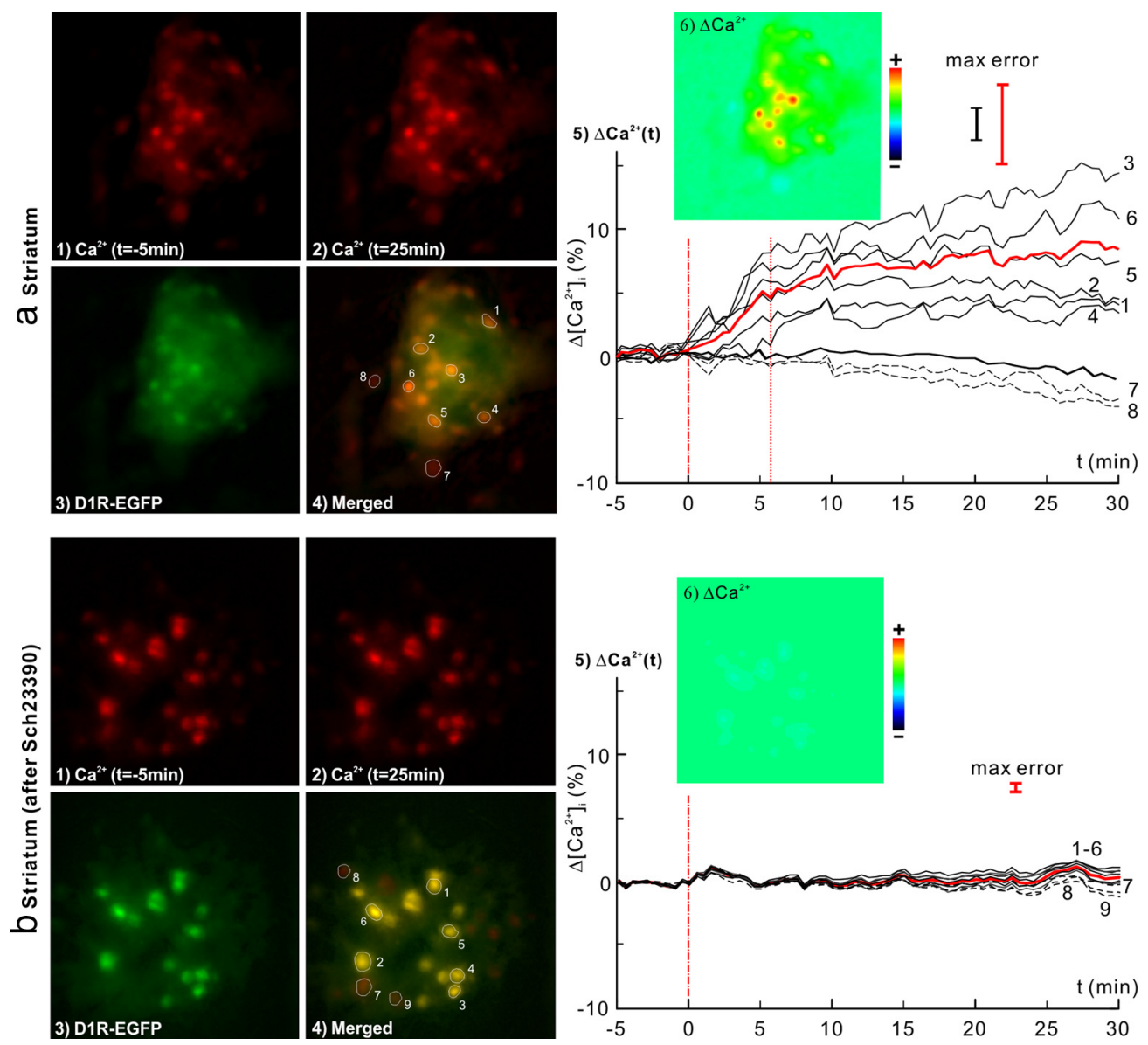

Figure 4. In vivo $\mu \mathrm{N}$ images of the dynamic $\left[\mathrm{Ca}^{2+}\right]_{\mathrm{i}}$ changes in response to cocaine $(8 \mathrm{mg} / \mathrm{kg}$, i.p.) in the striatum of D1R-EGFP mice without (a) and with (b) pretreatment of SCH23390 (D1 antagonist). 1, 2, $\left[\mathrm{Ca}^{2+}\right]_{\mathrm{i}}$ images at baseline $(t=-5 \mathrm{~min})$ and $t=25 \mathrm{~min}$ after cocaine injection. 3, EGFP images of D1R. 4, $\mathrm{Ca}^{2+}$ and EGFP images overlapped to identify $\left[\mathrm{Ca}^{2+}\right]_{\mathrm{i}}$ from D1R neurons. 5, $\Delta\left[\mathrm{Ca}^{2+}\right]_{\mathrm{i}}$ from individual D1R neurons (dark solid curves) and their averaged change (red bold curve), and from non-D1R cells (dashed curves). Cocaine-evoked [Ca $\left.{ }^{2+}\right]_{\mathrm{i}}$ increase was fast and plateaued at $t \approx 6 \mathrm{~min}$. The dark bold curve corresponds to the control study following saline injection. $6, \Delta\left[\mathrm{Ca}^{2+}\right]_{\mathrm{i}}$ image at $t=25$ min. Cocaine-evoked [Ca $\left.{ }^{2+}\right]_{\mathrm{i}}$ increase in striatal D1R-expressing neurons was $8.3 \pm 2.4 \%(n=14, p<0.0001)$; this increase was effectively inhibited by the $\mathrm{D} 1$ antagonist down to $0.5 \pm 0.2 \%(n=12, p<0.0001)$.

respectively. Although these non-GFP cells in the cortex could not be indentified by fluorescence in this Drd2-EGFP mouse, the similarities in their $\Delta\left[\mathrm{Ca}^{2+}\right]_{\mathrm{i}}$ responses to cocaine (i.e., $10-13 \%$ increase) to those observed in D1R neurons (i.e., $11-13 \%$ increase) of the Drd1-EGFP mouse (Fig. 3a4) suggest that the cortical $\left[\mathrm{Ca}^{2+}\right]_{\mathrm{i}}$ increases induced by cocaine are likely to reflect its effects in D1R neurons in cortical layers 5-6.

In the corpus callosum $\left[\mathrm{Ca}^{2+}\right]_{\mathrm{i}}$ fluorescence increased $3.8 \pm$ $4.2 \%(n=9, p=0.026)$ in non-GFP cells in this D1R-EGFP mouse and $7.0 \pm 6.6 \%(n=7, p=0.032)$ in the D2R-EGFP mouse respectively and these increases did not differ between the D1R-EGFP and the D2R-EGFP mice $(p=0.26)$. These cells were neither D1R- nor D2R-expressing neurons as indicated by the lack of EGFP fluorescence (Fig. 3a1,b1). Since cocaine has no specific binding in corpus callosum (Volkow et al., 1995), the $\left[\mathrm{Ca}^{2+}\right]_{\mathrm{i}}$ increases most likely reflect downstream effects.

Cocaine-induced dynamic $\left[\mathrm{Ca}^{2+}\right]_{\mathrm{i}}$ changes in D1R-expressing neurons and effects of D1R antagonists

To further study the dynamic features of $\Delta\left[\mathrm{Ca}^{2+}\right]_{\mathrm{i}}$ in individual $\mathrm{D} 1 \mathrm{R}$ neurons in response to cocaine, a $\mu \mathrm{N}$ probe was inserted into the striatum $(\sim 3 \mathrm{~mm}$ below the cortical surface) where D1R neurons were abundant. Figure $4 a$ shows the simultaneous images of $\operatorname{Rhod}_{2}-\left[\mathrm{Ca}^{2+}\right]_{\mathrm{i}}(1,2)$ and D1R-EGFP (3) fluorescence. Their merged image (4) allowed us to differentiate the $\left[\mathrm{Ca}^{2+}\right]_{\mathrm{i}}$ signals of D1R-expressing neurons (e.g., cells 1-6) from other cells in the field of view (e.g., cells 7-8). Figure $4 a 5$ shows the temporal $\left[\mathrm{Ca}^{2+}\right]_{\mathrm{i}}$ increases in $6 \mathrm{D} 1 \mathrm{R}$ neurons (solid lines) and the decreases in 2 non-D1R cells (dashed lines) in response to cocaine $\left(8 \mathrm{mg} / \mathrm{kg}\right.$, i.p.). The average $\left[\mathrm{Ca}^{2+}\right]_{\mathrm{i}}$ increases corresponded to $8.3 \pm 2.4 \%(n=14, p=0.0001)$ (red bold line). For comparison with control experiments, the response to saline administration $(8 \mathrm{ml} / \mathrm{kg}$, i.p.) was included in the bold dark curve, showing no $\left[\mathrm{Ca}^{2+}\right]_{\mathrm{i}}$ change in D1R neurons $(0.7 \pm 1.7 \%, n=13, p=0.19)$. This indicates that the measured $\left[\mathrm{Ca}^{2+}\right]_{\mathrm{i}}$ increases in striatal $\mathrm{D} 1 \mathrm{R}$-expressing neurons were caused by cocaine. The differential image in Figure $4 a 5$ (inset) clearly shows cocaine-induced $\left[\mathrm{Ca}^{2+}\right]_{\mathrm{i}}$ increases in all D1R neurons and decreases in non-D1R cells. It is noteworthy that the dynamic responses to cocaine differed between D1R-expressing neurons in striatum versus those in cortex. Specifically, cocaine-induced $\left[\mathrm{Ca}^{2+}\right]_{\mathrm{i}}$ increases in striatal D1R-expressing neurons were fast $\left(k_{1}=0.77 \pm 0.2 \% / \mathrm{min}\right)$ almost peaking within $8.3 \pm 2.3 \mathrm{~min}(m=4$, phase I) after cocaine administration, which was then followed by a plateau (phase II: $k_{2}=0.05 \pm 0.05 \% / \mathrm{min}, p=0.14, m=4$ ) for the remaining $\sim 22 \mathrm{~min}$ of the measurement. The dynamics (slope ratio) between these two phases in the striatal $\left[\mathrm{Ca}^{2+}\right]_{\mathrm{i}}$ increases in D1R-EGFP mice were significantly different $(r=0.06 \pm 0.23$, $p=0.64, m=4$ ), as summarized in Table 2. In contrast, the cocaine-induced $\left[\mathrm{Ca}^{2+}\right]_{\mathrm{i}}$ increases in D1R-expressing cortical 
Table 2. The striatal $\left[\mathrm{Ca}^{2+}\right]_{\mathrm{i}}$ changes in Drd1-EGFP mice

\begin{tabular}{llllllll}
\hline & \multicolumn{2}{l}{ Mouse number } & & & \\
\cline { 2 - 7 } D1 in striatum & 1 & 2 & 3 & 4 & Average & SD & \\
\hline$t_{\mathrm{p}}(\min )$ & 10.03 & 5.07 & 8.16 & 10 & 8.32 & 2.33 & - \\
$k_{1}(\% / \mathrm{min})$ & 0.58 & 0.97 & 0.92 & 0.60 & 0.77 & 0.20 & - \\
$k_{2}(\% / \mathrm{min})$ & 0.00 & 0.01 & 0.08 & 0.09 & 0.05 & 0.05 & 0.14 \\
$r=k_{2} / k_{1}$ & 0.00 & 0.01 & 0.09 & 0.15 & 0.06 & 0.23 & 0.64 \\
\hline
\end{tabular}
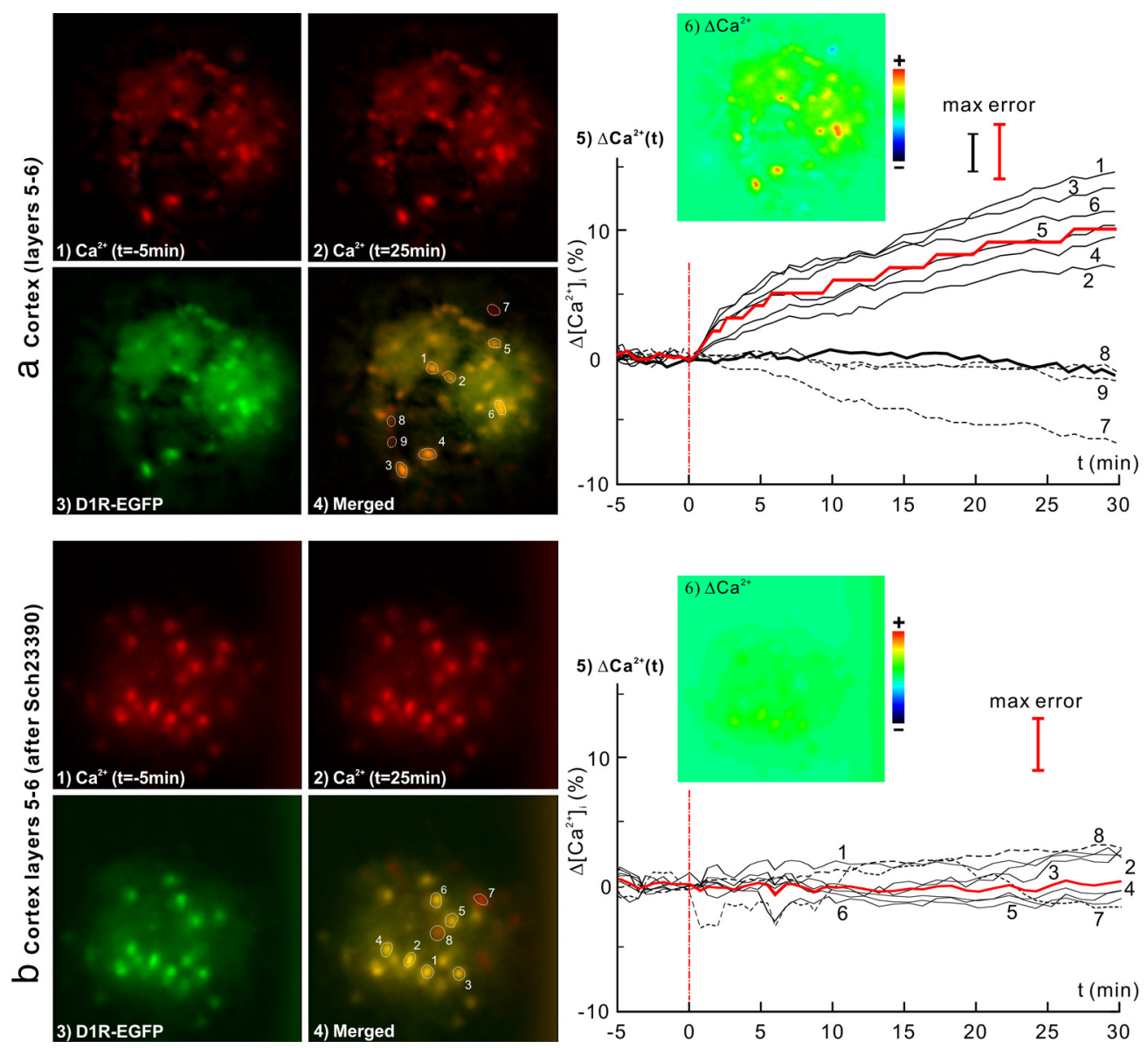

Figure 5. In vivo $\mu \mathrm{N}$ images of the dynamic $\left[\mathrm{Ca}^{2+}\right]_{\mathrm{i}}$ changes in response to cocaine $(8 \mathrm{mg} / \mathrm{kg}$, i.p.) in the cortex of D1R-EGFP mice without (a) and with (b) pretreatment of SCH23390 (D1 antagonist). 1, 2, $\left[\mathrm{Ca}^{2+}\right]_{\mathrm{i}}$ images at baseline $(t=-5 \mathrm{~min})$ and $t=25 \mathrm{~min}$ after cocaine injection. 3, EGFP images of D1R. 4, $\mathrm{Ca}^{2+}$ and EGFP images overlapped to identify $\left[\mathrm{Ca}^{2+}\right]_{\mathrm{i}}$ from D1R neurons. 5, $\Delta\left[\mathrm{Ca}^{2+}\right]_{\mathrm{i}}$ from individual D1R neurons (dark solid curves) and their averaged change (red bold curve), and from non-D1R cells (dashed curves). The dark bold curve corresponds to the control study following saline injection. 6, $\Delta\left[\mathrm{Ca}^{2+}\right]_{\mathrm{i}}$ image at $t=25$ min. Cocaine-evoked $\left[\mathrm{Ca}^{2+}\right]_{\mathrm{i}}$ increase in cortical D1R-expressing neurons was $9.2 \pm 2.4 \%(n=16, p<0.0001)$ and continued to increase over $t>30 \mathrm{~min}$; this increase was effectively inhibited by the $\mathrm{D} 1$ antagonist down to $0.4 \pm 4.0 \%(n=7, p=0.8)$.

neurons were fast in phase I $\left(k_{1}=0.70 \pm 0.15 \% / \mathrm{min}\right)$ and continued in phase II at a reduced rate $\left(k_{2}=0.11 \pm 0.01 \% / \mathrm{min}, p<\right.$ $\left.10^{-3}, m=4\right)$, indicating prolonged $\left[\mathrm{Ca}^{2+}\right]_{\mathrm{i}}$ increases in cortex versus in striatum $(p=0.019)$, as shown in Fig. $5 a 5$.

To assess whether blockade of D1R interfered with cocaineinduced $\left[\mathrm{Ca}^{2+}\right]_{\mathrm{i}}$ increases, D1R-EGFP mice were pretreated with SCH23390 (0.075 mg/kg, i.p. $)$, a selective D1R antagonist, at $t=$ -30 min before cocaine administration (Table 1, Experiment 3). Figures $4 b$ and $5 b$ show the corresponding $\mu \mathrm{N}$ images of D1REGFP mouse in response to cocaine $(8 \mathrm{mg} / \mathrm{kg}$, i.p.) after D1R antagonist pretreatment in striatum and cortex, respectively. On average, pretreatment with SCH23390 effectively suppressed the cocaine-induced $\left[\mathrm{Ca}^{2+}\right]_{\mathrm{i}}$ increases in D1R-expressing neurons to $0.5 \pm 0.3 \%(n=12, p<0.0001)$ in striatum and to $0.4 \pm 4.0 \%$ $(n=7, p=0.8)$ in the cortex of this mouse. This further confirmed that cocaine-induced $\left[\mathrm{Ca}^{2+}\right]_{\mathrm{i}}$ increases reflected activa- tion of D1R-expressing neurons in striatum and in cortex. Additionally, analysis of the crosstalk effects of SCH23390 on non-D1R cells showed that D1R blockade also inhibited cocaineinduced $\left[\mathrm{Ca}^{2+}\right]_{\mathrm{i}}$ decreases $(-0.9 \pm 0.6 \%, n=16, p<0.0001)$ in striatal D2R-expressing neurons (Fig. 7a5).

Cocaine-induced dynamic $\left[\mathrm{Ca}^{2+}\right]_{\mathrm{i}}$ changes in D2R-expressing neurons and effects of D2R antagonists

Figure $6 a$ shows images of $\operatorname{Rhod}_{2}-\left[\mathrm{Ca}^{2+}\right]_{\mathrm{i}}(1,2)$ and D2R-EGFP (3) fluorescence in the striatum. The temporal changes of $\left[\mathrm{Ca}^{2+}\right]_{i}$ fluorescence in striatum in response to cocaine are shown in Figure $6 a 5$. While $\left[\mathrm{Ca}^{2+}\right]_{\mathrm{i}}$ remained unchanged (bold dark line; $0.4 \pm 1.7 \%, n=12, p=0.43)$ after saline $(8 \mathrm{ml} / \mathrm{kg}$, i.p. $)$, cocaine decreased $\left[\mathrm{Ca}^{2+}\right]_{\mathrm{i}}$ fluorescence $(-9.0 \pm 1.5 \%, n=23, p<$ 0.0001 ) in striatal D2R-expressing neurons. Interestingly, in contrast to the initial fast $\left[\mathrm{Ca}^{2+}\right]_{\mathrm{i}}$ rise $(t \leq 8.3 \pm 2.3 \mathrm{~min}$, phase $\mathrm{I})$ 

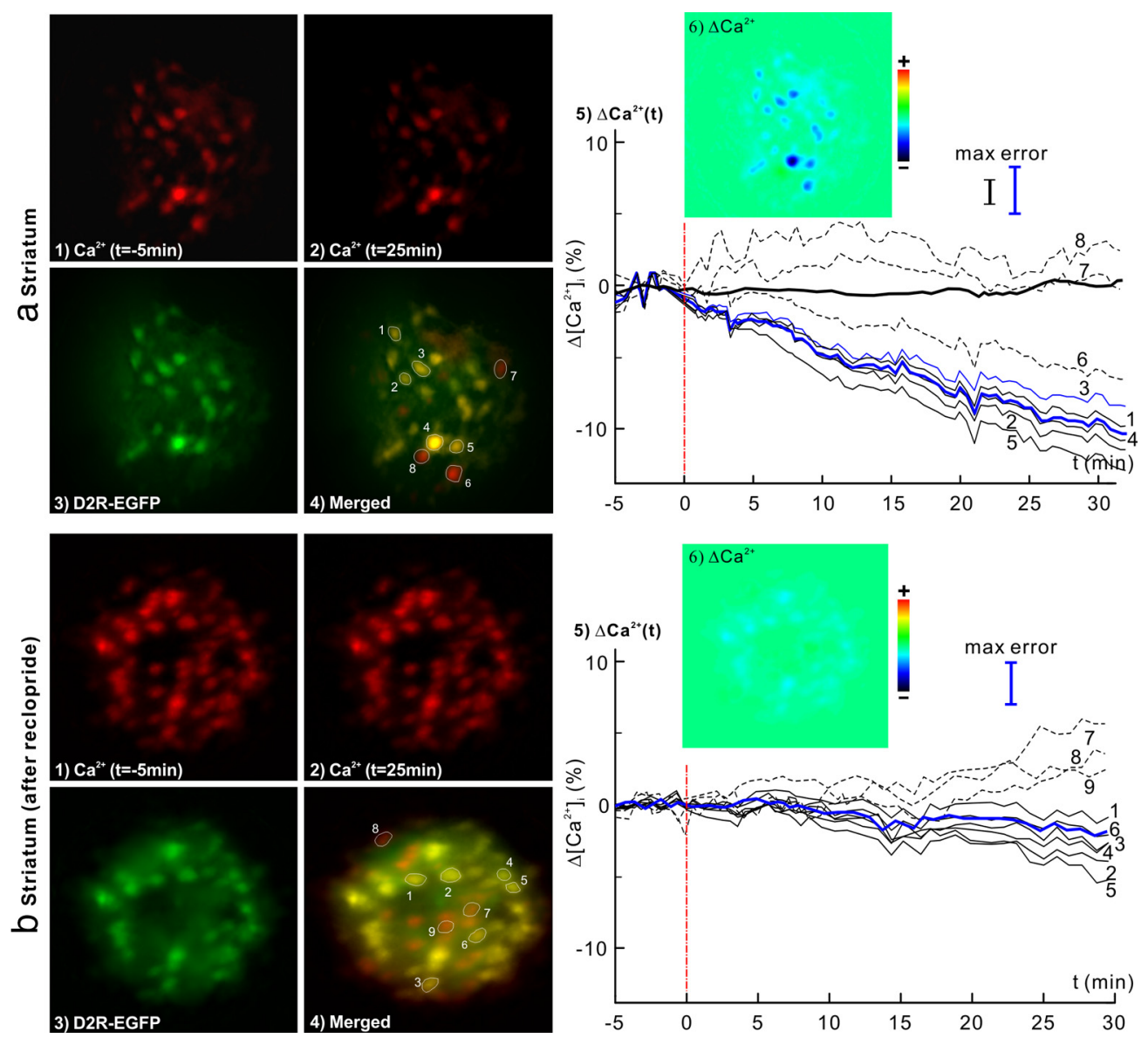

Figure 6. Dynamic $\left[\mathrm{Ca}^{2+}\right]_{\mathrm{i}}$ changes in response to cocaine $\left(8 \mathrm{mg} / \mathrm{kg}\right.$, i.p.) in the striatum of D2R-EGFP mice without $(\boldsymbol{a})$ and with $(\boldsymbol{b})$ raclopride $\left(\mathrm{D} 2\right.$ antagonist) pretreatment. 1, 2, $\left[\mathrm{Ca}{ }^{2+}\right]_{\mathrm{i}}$ images at baseline and $t=25$ min after cocaine injection. 3, EGFP images of D2R. 4, $\mathrm{Ca}^{2+}$ and EGFP images overlapped to identify $\left[\mathrm{Ca}^{2+}\right]_{\mathrm{i}}$ from D2Rneurons. 5, $\Delta\left[\mathrm{Ca}^{2+}\right]_{\mathrm{i}}$ from individual D2R neurons (dark solid curves) and their averaged change (blue bold curve), and from non-D1R cells (dashed curves). Cocaine-evoked $\left[\mathrm{Ca}^{2+}\right]_{\mathrm{i}}$ decrease was continuous overt $>30 \mathrm{~min}$. The dark bold curve correspond to the control study following saline injection. 6, $\Delta\left[\mathrm{Ca}^{2+}\right]_{\mathrm{i}}$ image at $t=25$ min. Cocaine-evoked a significant $\left[\mathrm{Ca}^{2+}\right]_{\mathrm{i}}$ decrease $(-9.0 \pm 1.5 \%, n=23, p<0.0001)$ in D2R neurons which was effectively inhibited by $\mathrm{D} 2$ antagonist down to $(-1.7 \pm 1.3 \%, n=27, p<0.0001)$.

Table 3. The striatal $\left[\mathrm{Ca}^{2+}\right]_{\mathrm{i}}$ changes in Drd2-EGFP mice

\begin{tabular}{|c|c|c|c|c|c|c|c|c|c|c|}
\hline \multirow[b]{2}{*}{ D2 in striatum } & \multicolumn{7}{|c|}{ Mouse number } & \multirow[b]{2}{*}{ Average } & \multirow[b]{2}{*}{ SD } & \multirow[b]{2}{*}{$p$ (average -1 ) } \\
\hline & 1 & 2 & 3 & 4 & 5 & 6 & 7 & & & \\
\hline$k_{1}(\% / \min )$ & -0.47 & -0.47 & -0.64 & -0.30 & -0.30 & -0.33 & -0.33 & -0.40 & 0.13 & - \\
\hline$k_{2}(\% / \mathrm{min})$ & -0.34 & -0.67 & -0.49 & -0.24 & -0.33 & -0.37 & -0.27 & -0.39 & 0.15 & - \\
\hline$r=k_{2} / k_{1}$ & 0.74 & 1.44 & 0.77 & 0.80 & 1.11 & 1.12 & 0.82 & 0.97 & 0.26 & 0.77 \\
\hline
\end{tabular}

recorded in striatal D1R neurons (Fig. 4a5, Table 2), the $\left[\mathrm{Ca}^{2+}\right]_{\mathrm{i}}$ in striatal D2R neurons continued to decrease over $t>30 \mathrm{~min}$ post cocaine. The similar fitting analysis applied above to the D1R-expressing neurons in Drd1-EGFP mice was also applied to D2R-expressing striatal neurons in Drd2-EGFP mice (as illustrated in Fig. $2 b)$. The slope ratio of $\left[\mathrm{Ca}^{2+}\right]_{\mathrm{i}}$ decrease between the $0-10 \min \left(k_{1}=-0.40 \pm 0.13 \% / \mathrm{min}\right)$ and the $10-30 \mathrm{~min}\left(k_{2}=\right.$ $-0.39 \pm 0.15 \% / \mathrm{min})$ periods did not differ significantly $(r=$ $0.97 \pm 0.26, p=0.77, m=7$ ) after cocaine administration, indicating a single-phase continuous decrease of $\left[\mathrm{Ca}^{2+}\right]_{\mathrm{i}}$ over the 30 min period of the measurements in D2R-expressing neurons (Table 3).

To assess whether blockade of D2R receptors interfered with cocaine-induced striatal $\left[\mathrm{Ca}^{2+}\right]_{\mathrm{i}}$ decreases, D2R-EGFP mice were pretreated with raclopride (3 mg/kg, i.p.), a D2/D3 antagonist, at $t=-30 \mathrm{~min}$ before cocaine administration (Table 1 , Experiment 3). Fig. $6 b 5$ shows that on average, pretreatment with raclopride suppressed cocaine-induced $\left[\mathrm{Ca}^{2+}\right]_{\mathrm{i}}$ decreases in D2R neurons to $-1.7 \pm 1.3 \%(n=27, p<0.0001)$ in that experiment. In addition, an analysis of the crosstalk effects of raclopride on striatal D1R cells showed that D2R blockade also partially inhibited the $\left[\mathrm{Ca}^{2+}\right]_{\mathrm{i}}$ increases down to $2.5 \pm 0.7 \%(n=15, p<$ 0.0001 ) in Drd1-EGFP mice (Fig. 7b5, compared with $8.3 \pm 2.4 \%$ increases in Fig. 4a5), although the fast $\left[\mathrm{Ca}^{2+}\right]_{\mathrm{i}}$ rise (phase I) still occurred.

Comparison of cocaine-induced dynamic $\left[\mathrm{Ca}^{2+}\right]_{\mathrm{i}}$ changes in striatal D1R- and D2R-expressing neurons

Comparisons between the slopes for the $\left[\mathrm{Ca}^{2+}\right]_{\mathrm{i}}$ changes in D1Rversus D2R-expressing neurons showed that $k_{1}(=0.77 \pm 0.20 \% /$ min, Table 2) in D1R-expressing neurons of Drd1-EGFP mice was significantly larger than the $k_{1}(=-0.40 \pm 0.13 \% / \mathrm{min}$, Table 3 ) in D2R-expressing neurons of Drd2-EGFP mice, indicating that the $\left[\mathrm{Ca}^{2+}\right]_{\mathrm{i}}$ increase of D1R-expressing striatal neurons is 

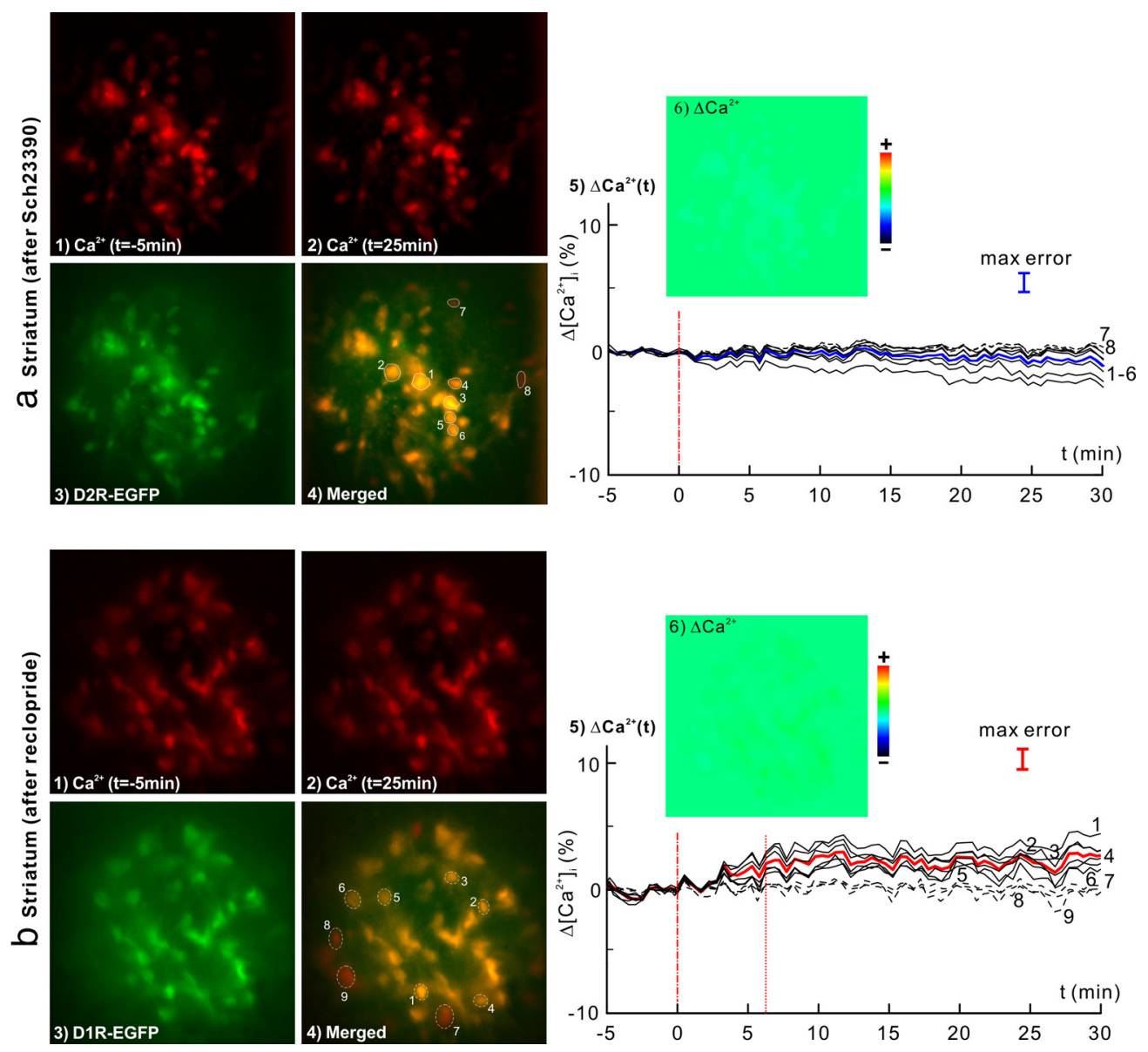

Figure 7. Crosstalk of D1R $(\boldsymbol{a})$ and $\mathrm{D} 2 \mathrm{R}(\boldsymbol{b})$ antagonists on the $\left[\mathrm{Ca}^{2+}\right]_{\mathrm{i}}$ changes of striatal D1R-and D2R-expressing neurons in response to cocaine $\left(8 \mathrm{mg} / \mathrm{kg}\right.$, i.p.). $1,2,\left[\mathrm{Ca}^{2+}\right]_{\mathrm{i}}$ images at baseline and $t=25$ min after cocaine injection. 3, EGFP images of D2R $(\boldsymbol{a})$ and D1R $(\boldsymbol{b})$ neurons. $4, \mathrm{Ca}^{2+}$ and EGFP images overlapped to identify $\left[\mathrm{Ca}^{2+}\right]_{\mathrm{i}}$ from D2R $(\boldsymbol{a})$ and D1R $(\boldsymbol{b})$ neurons. 5, $\Delta\left[\mathrm{Ca}^{2+}\right]_{\mathrm{i}}$ from individual D2R ( $\boldsymbol{a}$ ) and D1R ( $\boldsymbol{b}$ ) neurons (dark solid curves), and their averaged changes (blue bold curve for D2R neurons, red bold curve for D1R neurons). $6, \Delta\left[\mathrm{Ca}^{2+}\right]_{\mathrm{i}}$ images at $t=25$ min. Cocaine-evoked $\left[\mathrm{Ca}^{2+}\right]_{\mathrm{i}}$ decrease in D2R neurons were effectively inhibited by the D1 antagonist down to $-0.9 \pm 0.6 \%(n=16, p<0.0001)$, whereas cocaine-evoked [Ca $\left.{ }^{2+}\right]_{\mathrm{i}}$ increase in striatal D1R neurons were partially inhibited by the D2 antagonist from $8.3 \pm 2.4 \%$ (Fig. $4 a 5)$ to $2.5 \pm 0.7 \%(n=15, p<0.0001)$.

more rapid than the decrease of $\left[\mathrm{Ca}^{2+}\right]_{\mathrm{i}}$ in D2R-expressing striatal cells $(p=0.0024)$.

\section{Summary of results}

Figure 8 summarizes our findings in Drd1-EGFP (Fig. 8a) and Drd2-EGFP mice (Fig. 8b). Cocaine-induced $\left[\mathrm{Ca}^{2+}\right]_{\mathrm{i}}$ increases in D1R neurons were $11.1 \pm 2.2 \%$ in cortical layers 5-6 $(m=4$ mice, $p=0.0021)$ and $10.6 \pm 3.2 \%$ in striatum $(m=4$ mice, $p=$ 0.0067 ) and pretreatment with the D1R antagonist (SCH233900) suppressed $\Delta\left[\mathrm{Ca}^{2+}\right]_{\mathrm{i}}$ to $2.2 \pm 1.7 \%$ in cortex ( $80 \%$ suppression; $p=0.0022)$ and $0.9 \pm 0.9 \%$ in striatum (92\% suppression; $p=$ $0.0039)$. Cocaine-induced $\left[\mathrm{Ca}^{2+}\right]_{\mathrm{i}}$ decreases in striatal D2R neurons were $-10.4 \pm 5.8 \%(m=7$ mice, $p=0.0033)$ and pretreatment with the D2R antagonist (raclopride) suppressed it to $-1.1 \pm 1.5 \%$ (90\% suppression; $p=0.014$ ).

Noteworthily, the D1R antagonist inhibited the cocaineinduced $\left[\mathrm{Ca}^{2+}\right]_{\mathrm{i}}$ decreases in striatal D2R neurons to $-0.5 \pm$ $0.4 \%$ (95\% suppression; $p=0.0050)$ and the $\mathrm{D} 2 \mathrm{R}$ antagonist inhibited the cocaine-induced $\left[\mathrm{Ca}^{2+}\right]_{\mathrm{i}}$ increase in striatal D1R neurons to $2.7 \pm 0.3 \%$ (75\% suppression $p=0.0084$ ). Control experiments with saline administration showed no significant $\left[\mathrm{Ca}^{2+}\right]_{\mathrm{i}}$ changes in cortex $(0.0 \pm 1.3 \% ; m=4$ mice, $p=0.92)$ or in striatum $(0.2 \pm 1.7 \% ; m=3$ mice, $p=0.88$ for D1R-EGFP mice and $-0.5 \pm 1.6 \%, m=3$ mice, $p=0.68$ for D2R-EGFP mice).

\section{Discussion}

Cocaine's ability to induce fast DA increases is crucial for its rewarding effects and may trigger the neuroplastic changes associated with addiction. However, the dynamics of the molecular mechanisms by which cocaine induces reward are still poorly understood. Increases in D1R stimulation are associated with sensitized responses to cocaine whereas reduced striatal D2R signaling is associated with vulnerability for compulsive cocaine administration (Bertran-Gonzalez et al., 2008; Hikida et al., 2010). Thus, cocaine's stimulation of D1R, which resulted in fast neuronal activation $\left(\mathrm{Ca}^{2+}\right.$ increased rapidly within $8.32 \pm 2.33$ min) and its stimulation of $\mathrm{D} 2 \mathrm{R}$, which resulted in progressive neuronal deactivation $\left(\mathrm{Ca}^{2+}\right.$ decreased continuously throughout $30 \mathrm{~min}$ ), could mediate cocaine reward.

In the striatum, stimulation of the direct pathway, which expresses D1R, facilitates locomotor behavior (basal and cocaine induced), whereas stimulation of the indirect pathway, which expresses D2R, inhibits it (Albin et al., 1989; Bateup et al., 2010). A similar role for the direct (stimulatory) and the indirect (inhibitory) pathways may occur for DA-mediated reward. Indeed, in striatum stimulation of D1R-expressing neurons enhanced the rewarding effects of cocaine whereas stimulation of D2Rexpressing neurons attenuated them (Hikida et al., 2010). Similarly disruption of the indirect pathways (D2R mediated) 


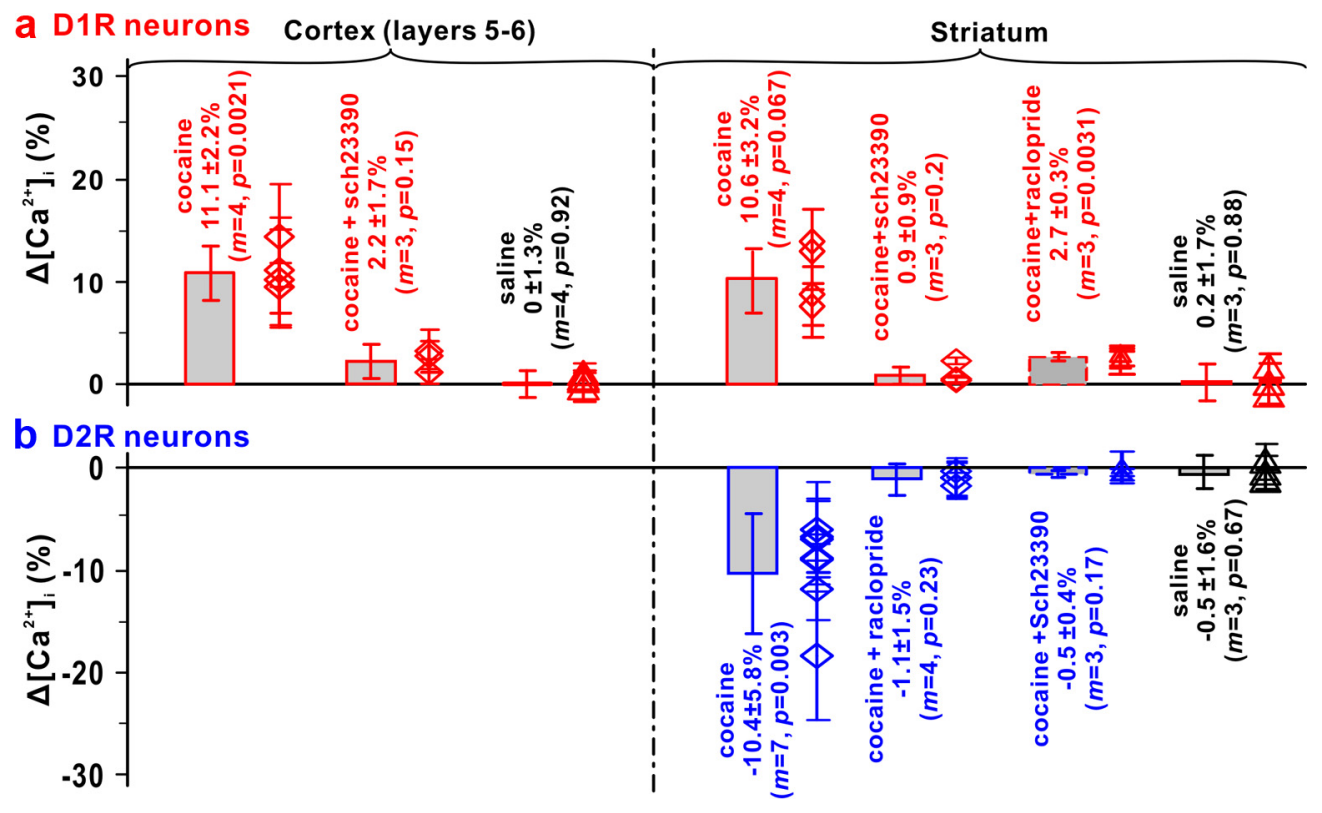

Figure 8. Summary of cocaine-evoked $\Delta\left[\mathrm{Ca}^{2+}\right]_{i}$ in D1R $(\boldsymbol{a})$-and D2R $(\boldsymbol{b})$-expressing neurons in cortical and striatal regions. The mean \pm SD data are represented by diamonds and error bars for each mouse and by boxes and error bars for each experiment group. The statistics show that cocaine (shaded boxes) induced $\left[\mathrm{Ca}^{2+}\right]_{\mathrm{i}}$ increases in D1R neurons in both cortex and striatum (red), but it induced $\left[\mathrm{Ca}^{2+}\right]_{i}$ decreases in D2Rneurons in striatum (blue). Cocaine-induced [ $\left.\mathrm{Ca}^{2+}\right]_{\mathrm{i}}$ increases (D1Rneurons) and decreases (D2R neurons) were significantly diminished or abolished with pretreatment with D1R (SCH233900) or D2R antagonist (raclopride). In striatum, D1Rantagonisteffectively blocked cocaine-induced $\left[\mathrm{Ca}^{2+}\right]_{\mathrm{i}}$ decrease in D2R neurons, whereas D2R antagonist only partially $(\sim 75 \%)$ blocked $\left[\mathrm{Ca}^{2+}\right]_{\mathrm{i}}$ increase in D1R neurons. No significant $\left[\mathrm{Ca}^{2+}\right]_{\mathrm{i}}$ changes were detected in the control groups with saline challenge $(8 \mathrm{ml} / \mathrm{kg}$, i.p.) in D1R-and D2R-expressing neurons (black). ( $m$, number of mice).

facilitated behavioral sensitization to amphetamine whereas decreasing the excitability of the direct pathway (D1R mediated) impaired it (Ferguson et al., 2011). Thus our findings showing that cocaine, which is a highly rewarding drug, induced activation of the direct pathway and inactivation of the indirect pathway are consistent with opposing effects of the direct and indirect pathway in reward (Durieux et al., 2009).

Interestingly, the dynamics of cocaine's effects on the direct and indirect striatal DA pathways differed: stimulation of D1R neurons was faster than of D2R neurons but the stimulation of D2R neurons was longer-lasting. These distinct dynamic responses may underlie the rate dependency for cocaine's rewarding effects; the faster its effects the greater its rewarding effects (Balster and Schuster, 1973; Volkow et al., 1997; Wakabayashi et al., 2010). Since D1Rs are low-affinity receptors, they will be directly stimulated by DA only during the period when cocaineinduced DA increases are at their peak, which would occur during the first $5 \mathrm{~min}$ of cocaine's intravenous injection or the first $10 \mathrm{~min}$ with intraperitoneal injection. On the other hand, the longer-lasting cocaine-induced DA stimulation of D2R (deactivating $\mathrm{D} 2 \mathrm{R}$-expressing neurons), which is stimulated by much lower DA concentrations (than D1R) and remains 30-40 min after cocaine administration, may serve to facilitate cocaine's rewarding effects and favor subsequent administration. Thus the deactivation of $\mathrm{D} 2 \mathrm{R}$-expressing neurons in striatum by acute cocaine may facilitate the rewarding effects of activation of striatal D1R-expressing neurons by removing their opposing role on reward. Because the deactivation of D2R-expressing neurons was prolonged this could facilitate repeated administration of cocaine beyond the period when cocaine induces peak DA increases and may contribute to the craving that follows the short-lasting high induced by cocaine (Breiter et al., 1997).

As expected, pretreatment with a D1R antagonist effectively inhibited cocaine-induced $\left[\mathrm{Ca}^{2+}\right]_{\mathrm{i}}$ increase in D1R neurons (Figs. $4 b 5,5 b 5$ ) and pretreatment with a D2R antagonist effec- tively inhibited cocaine-induced $\left[\mathrm{Ca}^{2+}\right]_{\mathrm{i}}$ decrease in D2R neurons (Fig. 6b5). However, the D1R antagonist also interfered with cocaine's effects in D2R-expressing neurons and the D2R antagonists with cocaine's effects in D1R-expressing neurons (Fig. $7 a, b)$. These interactions were not symmetrical. Specifically, whereas the D1R antagonist almost completely inhibited cocaine-induced $\left[\mathrm{Ca}^{2+}\right]_{\mathrm{i}}$ decreases in striatal D2R neurons (Fig. $7 a 5)$ the D2R antagonist only partially inhibited cocaine-induced $\left[\mathrm{Ca}^{2+}\right]_{\mathrm{i}}$ increases in striatal D1R neurons (Fig. 7b5). This could explain why cocaine is still rewarding in individuals treated with antipsychotics drugs, which block D2R (Van Eden et al., 1987), as it would still be able to activate a subset of D1R-expressing neurons. The mechanisms of these interactions are unclear. Cocaine is a nonselective indirect DA agonist and though we assume that the crosstalk reflects DA effects we cannot rule out the possibility that these could be mediated by its noradrenergic or serotonergic actions. Indeed medium spiny neurons express serotonin (5HT) receptors (Cornea-Hébert et al., 1999) and neuronal colocalization of D2R and 5HT2R (Borroto-Escuela et al., 2010). Similarly the crosstalk could reflect nonspecific effects of the antagonists used. However it is also possible that they could reflect dendritic interaction between cells (Spangler et al., 1996), long-loop interactions between pathways (Gerfen, 1992; Hallett, 1993) or interactions between cellular and local circuits (Braun et al., 1997). In the current study it is not possible to determine whether the interactions occur at the level of individual neurons, local circuits or within distributed brain systems (Braun et al., 1997), and this merits further investigation.

In the cortex DA terminals innervate predominantly pyramidal cells in layers 5-6 (Descarries et al., 1987; Goldman-Rakic et al., 1989; Ohuoha et al., 1997) and the expression of D1R is much higher than that of D2R (Berger et al., 1991; Ohuoha et al., 1997). Our results confirm a relatively high expression of D1R neurons in cortical layers 5-6 of the motor-sensory cortices (Fig. 3a1), 
and very low expression of D2R neurons (Fig. 3b1) as reported by in vitro brain slice studies (Gong et al., 2003). In the cortex just as in the striatum cocaine increased $\left[\mathrm{Ca}^{2+}\right]_{\mathrm{i}}$ in D1R-expressing neurons but the dynamics of this effect differ. Whereas in the striatum the $\left[\mathrm{Ca}^{2+}\right]_{\mathrm{i}}$ increases peaked between 6 and $10 \mathrm{~min}$ in the cortex they were still rising at $30 \mathrm{~min}$. This is likely to reflect in part the much lower concentrations of DA transporters and or DA autoreceptors in cortex than in striatum that would affect the dynamics of cocaine-induced DA increases in these two brain regions. Although most of the work on DA modulation via D1R (and to a lesser extent D2R) of cortical function has focused on the prefrontal cortex (Goldman-Rakic, 1992), D1R also modulates sensory-motor cortices (Chu et al., 2010). Also while most studies on cocaine's rewarding and addictive effects in cortex have concentrated on the prefrontal cortex, sensory-motor cortices have also been implicated (Steiner and Kitai, 2001; Drouin and Waterhouse, 2004).

Limitations for this study include the fact that we recorded from the dorsal striatum and not from the nucleus accumbens, which is an area implicated in drug reward (Di Chiara and Imperato, 1988; Koob and Bloom, 1988). However there is increasing evidence of the importance of cocaine's effects in the dorsal striatum in its addictive effects (Volkow et al., 2007). Also this study focused only on the acute effects of cocaine and future studies that evaluate the effects of repeated cocaine administration are necessary to distinguish the adaptation responses in these two pathways that may contribute to addiction. In addition, with the $\mu$-prism we image a large area (i.e., a $1.8 \times 0.2 \mathrm{~mm}^{2}$ panorama) and to avoid photon bleaching for detection of $\left[\mathrm{Ca}^{2+}\right]_{i}$ fluorescence we shortened the imaging time and selected for imaging the regions in the striatum that had the strongest GFP signal (GFP does not easily bleach). As the GFP distribution differed in Drd1- and Drd2-EGFP mice, the striatal region imaged might not be exactly the same for the Drd1- and the Drd2-EGFP mice shown in Figure 3, $a$ and $b$, limiting their comparability in terms of cell distribution and density. Our $\left[\mathrm{Ca}^{2+}\right]_{\mathrm{i}}$ measurements in the non-GFP cells are likely to be of lower quality than in GFP cells (GFP cells were used to focus the microscope and thus less likely to be influenced by scattering light from neighboring cells), which could explain their smaller $\left[\mathrm{Ca}^{2+}\right]_{i}$ changes. Also we cannot identify with certainty whether these non-GFP cells correspond to $\mathrm{D} 2 \mathrm{R}$ or D1R-expressing neurons. Another limitation is that our studies were done on anesthetized animals and anesthetics can modify cocaine effects (Du et al., 2009). Finally a recent paper showed D2R overexpression in D2R EGFP mice that affected DA signaling including drug responses (Kramer et al., 2011). However Kramer's paper used homozygous D2R BAC transgenic mice, which creates two chromosomes with the insertion whereas we used heterozygous mice to avoid phenotypes due to the insertion. Thus Kramer's findings do not apply to our mice.

In summary, this study implicates the importance of signal transduction via the activation of D1R-expressing neurons and the inhibition of D2R-expressing neurons in cocaine's pharmacological effects and provide preliminary evidence that the rate dependency of cocaine's effect may relate to its fast activation of D1R-expressing striatal neurons in contrast to the much longer deactivation of neurons D2R. We also uncover a crosstalk between D1R- and D2R-expressing neurons in striatum when challenged with cocaine. Finally our findings also highlight the power of optical imaging for dissecting the cellular and molecular actions of cocaine in vivo.

\section{References}

Albin RL, Young AB, Penney JB (1989) The functional anatomy of basal ganglia disorders. Trends Neurosci 12:366-375.

Balster RL, Schuster CR (1973) Fixed-interval schedule of cocaine reinforcement: effect of dose and infusion duration. J Exp Anal Behav 20:119-129.

Bateup HS, Santini E, Shen W, Birnbaum S, Valjent E, Surmeier DJ, Fisone G, Nestler EJ, Greengard P (2010) Distinct subclasses of medium spiny neurons differentially regulate striatal motor behaviors. Proc Natl Acad Sci U S A 107:14845-14850.

Berger B, Gaspar P, Verney C (1991) Dopaminergic innervation of the cerebral cortex: unexpected differences between rodents and primates. Trends Neurosci 14:21-27.

Bertran-Gonzalez J, Bosch C, Maroteaux M, Matamales M, Hervé D, Valjent E, Girault JA (2008) Opposing patterns of signaling activation in dopamine D1 and D2 receptor-expressing striatal neurons in response to cocaine and haloperidol. J Neurosci 28:5671-5685.

Borroto-Escuela DO, Romero-Fernandez W, Tarakanov AO, Marcellino D, Ciruela F, Agnati LF, Fuxe K (2010) Dopamine D2 and 5-hydroxytryptamine 5- $\mathrm{HT}\left({ }_{2} \mathrm{~A}\right)$ receptors assemble into functionally interacting heteromers. Biochem Biophys Res Commun 401:605-610.

Braun AR, Laruelle M, Mouradian MM (1997) Interactions between D1 and D2 dopamine receptor family agonists and antagonists: the effects of chronic exposure on behavior and receptor binding in rats and their clinical implications. J Neural Transm 104:341-362.

Breiter HC, Gollub RL, Weisskoff RM, Kennedy DN, Makris N, Berke JD, Goodman JM, Kantor HL, Gastfriend DR, Riorden JP, Mathew RT, Rosen BR, Hyman SE (1997) Acute effects of cocaine on human brain activity and emotion. Neuron 19:591-611.

Caine SB, Koob GF (1994) Effects of dopamine D-1 and D-2 antagonists on cocaine self-administration under different schedules of reinforcement in the rat. Pharmacology 270:209-218.

Chia TH, Levene MJ (2009) Multi-layer in vivo imaging of neocortex using a microprism. J Neurophysiol 102:1310-1314.

Chia TH, Levene MJ (2010) Multi-layer in vivo imaging of neocortex using a microprism. Cold Spring Harb Protoc 8:pdb.prot5476.

Choleris E, Clipperton-Allen AE, Gray DG, Diaz-Gonzalez S, Welsman RG (2011) Differential effects of dopamine receptor d1-type and d2-type antagonists and phase of the estrous cycle on social learning of food preferences, feeding, and social interactions in mice. Neuropsychopharmacology 36:1689-1702.

Chu HY, Yang Z, Zhao B, Jin GZ, Hu GY, Zhen X (2010) Activation of phosphatidylinositol-linked D1-like receptors increases spontaneous glutamate release in rat somatosensory cortical neurons in vitro. Brain Res 1343:20-27.

Cornea-Hébert V, Riad M, Wu C, Singh SK, Descarries L (1999) Cellular and subcellular distribution of the serotonin 5-Ht2a receptor in the central nervous system of adult rat. J Comp Neurol 409:187-209.

Descarries L, Lemay B, Doucet G, Berger B (1987) Regional and laminar density of the dopamine innervation in the adult rat cerebral cortex. Neuroscience 21:807-824.

Di Chiara G, Imperato A (1988) Drugs abused by humans preferentially increase synaptic dopamine concentrations in the mesolimbic system of freely moving rats. Proc Natl Acad Sci U S A 85:5274-5278.

Doherty JM, Masten VL, Powell SB, Ralph RJ, Klamer D, Low MJ, Geyer MA (2008) Contributions of dopamine D1, D2, and D3 receptor subtypes to the disruptive effects of cocaine on prepulse inhibition in mice. Neuropsychopharmacology 33:2648-2656.

Drouin C, Waterhouse BD (2004) Cocaine-induced vs. behaviour-related alterations of spontaneous and evoked discharge of somatosensory cortical neurons. Eur J Neurosci 19:1016-1026.

Du C, Tully M, Volkow ND, Schiffer WK, Yu M, Luo Z, Koretsky AP, Benveniste H (2009) Differential effects of anesthetics on cocaine's pharmacokinetic and pharmacodynamic effects in brain. Eur J Neurosci 30:1565-1575.

Durieux PF, Bearzatto B, Guiducci S, Buch T, Waisman A, Zoli M, Schiffmann SN, de Kerchove d'Exaerde A (2009) D2R striatopallidal neurons inhibit both locomotor and drug reward processes. Nat Neurosci 12:393-395.

España RA, Roberts DC, Jones SR (2008) Short-acting cocaine and longacting GBR-12909 both elicit rapid dopamine uptake inhibition following intravenous delivery. Neuroscience 155:250-257.

Ferguson SM, Eskenazi D, Ishikawa M, Wanat MJ, Phillips PE, Dong Y, Roth 
BL, Neumaier JF (2011) Transient neuronal inhibition reveals opposing roles of indirect and direct pathways in sensitization. Nat Neurosci 14:22-24.

Gerfen CR (1992) The neostriatal mosaic: multiple levels of compartmental organization. J Neural Transm Suppl 36:43-59.

Goldman-Rakic PS (1992) Working memory and the mind. Sci Am 267:110-117.

Goldman-Rakic PS, Leranth C, Williams SM, Mons N, Geffard M (1989) Dopamine synaptic complex with pyramidal neurons in primate cerebral cortex. Proc Natl Acad Sci U S A 86:9015-9019.

Gong S, Zheng C, Doughty ML, Losos K, Didkovsky N, Schambra UB, Nowak NJ, Joyner A, Leblanc G, Hatten ME, Heintz N (2003) A gene expression atlas of the central nervous system based on bacterial artificial chromosomes. Nature 425:917-925.

Goto Y, Grace AA (2005) Dopaminergic modulation of limbic and cortical drive of nucleus accumbens in goal-directed behavior. Nat Neurosci 8:805-812.

Hallett M (1993) Physiology of basal ganglia disorders: an overview. Can J Neurol Sci 20:177-183.

Helmchen F, Denk W (2002) New developments in multiphoton microscopy. Curr Opin Neurobiol 12:593-601.

Helmchen F, Waters J (2002) $\mathrm{Ca}^{2+}$ imaging in the mammalian brain in vivo. Eur J Pharmacol 447:119-129.

Hikida T, Kimura K, Wada N, Funabiki K, Nakanishi S (2010) Distinct roles of synaptic transmission in direct and indirect striatal pathways to reward and aversive behavior. Neuron 66:896-907.

Hof PR, Young WG (2000) Comparative cytoarchitectonic atlas of the C57BL/6 and 129 Sv mouse brains. New York: Elsevier.

Jung JC, Mehta AD, Aksay E, Stepnoski R, Schnitzer MJ (2004) In vivo mammalian brain imaging using one- and two-photon fluorescence microendoscopy. J Neurophysiol 92:3121-3133.

Koob GF, Bloom FE (1988) Cellular and molecular mechanisms of drug dependence. Science 242:715-723.

Kramer PF, Christensen CH, Hazelwood LA, Dobi A, Bock R, Sibley DR, Mateo Y, Alvarez VA (2011) Dopamine D2 receptor overexpression alters behavior and physiology in Drd2-EGFP mice. J Neurosci 31:126-132.

Lange N, Hamann M, Shashidharan P, Richter A (2011) Behavioural and pharmacological examinations in a transgenic mouse model of earlyonset torsion dystonia. Pharmacol Biochem Behav 97:647-655.

Levene MJ, Dombeck DA, Kasischke KA, Molloy RP, Webb WW (2004) In vivo multiphoton microscopy of deep brain tissue. J Neurophysiol 91:1908-1912.

Lobo MK, Covington HE 3rd, Chaudhury D, Friedman AK, Sun H, DamezWerno D, Dietz DM, Zaman S, Koo JW, Kennedy PJ, Mouzon E, Mogri
M, Neve RL, Deisseroth K, Han MH, Nestler EJ (2010) Cell type-specific loss of BDNF signaling mimics optogenetic control of cocaine reward. Science 330:385-390.

Ohuoha DC, Maxwell JA, Thomson LE 3rd, Cadet JL, Rothman RB (1997) Effect of dopamine receptor antagonists on cocaine subjective effects: a naturalistic case study. J Subst Abuse Treat 14:249-258.

Paxinos G, Franklin KBJ (2004) The mouse brain in stereotaxic coordinates, Ed 2. San Diego: Academic.

Spangler R, Zhou Y, Maggos CE, Zlobin A, Ho A, Kreek MJ (1996) Dopamine antagonist and "binge" cocaine effects on rat opioid and dopamine transporter mRNAs. Neuroreport 7:2196-2200.

Steiner H, Kitai ST (2001) Unilateral striatal dopamine depletion: timedependent effects on cortical function and behavioural correlates. Eur J Neurosci 14:1390-1404.

Sudhof TC (2004) The synaptic vesicle cycle. Annu Rev Neurosci 27:509-547.

Surmeier DJ, Bargas J, Hemmings HC Jr, Nairn AC, Greengard P (1995) Modulation of calcium currents by a D1 dopaminergic protein kinase/ phosphatase cascade in rat neostriatal neurons. Neuron 14:385-397.

Van Eden CG, Hoorneman EM, Buijs RM, Matthijssen MA, Geffard M, Uylings HB (1987) Immunohistochemical localization of dopamine in the prefrontal cortex of the rat at the light, electron microscopical level. Neuroscience 22:849-862.

Volkow ND, Fowler JS, Logan J, Gatley SJ, Dewey SL, MacGregor RR, Schlyer DJ, Pappas N, King P, Wang GJ, Wolf AP (1995) Carbon-11-cocaine binding compared at subpharmacological and pharmacological doses: a PET study. J Nucl Med 36:1289-1297.

Volkow ND, Wang GJ, Fischman MW, Foltin RW, Fowler JS, Abumrad NN, Vitkun S, Logan J, Gatley SJ, Pappas N, Hitzemann R, Shea CE (1997) Relationship between subjective effects of cocaine and dopamine transporter occupancy. Nature 386:827-830.

Volkow ND, Fowler JS, Wang GJ, Swanson JM, Telang F (2007) Dopamine in drug abuse and addiction: results of imaging studies and treatment implications. Arch Neurol 64:1575-1579.

Wakabayashi KT, Weiss MJ, Pickup KN, Robinson TE (2010) Rats markedly escalate their intake and show a persistent susceptibility to reinstatement only when cocaine is injected rapidly. J Neurosci 30: $11346-11355$.

Williams SN, Undieh AS (2010) Brain-derived neurotrophic factor signaling modulates cocaine induction of reward-associated ultrasonic vocalization in rats. J Pharmacol Exp Ther 332:463-468.

Zipfel WR, Williams RM, Webb WW (2003) Nonlinear magic: multiphoton microscopy in the biosciences. Nat Biotechnol 21:1369-1377. 